\title{
Modulation of estrogen receptor- $\beta$ isoforms by phytoestrogens in breast cancer cells
}

\author{
VERA CAPPELLETTI ${ }^{1}$, PATRIZIA MIODINI ${ }^{1}$, GIOVANNI DI FRONZO ${ }^{2}$ and MARIA GRAZIA DAIDONE ${ }^{1}$ \\ ${ }^{1}$ Department of Experimental Oncology, Unit \#10, Istituto Nazionale per lo Studio e la Cura dei Tumori; \\ ${ }^{2}$ Institute of Biomedical Technologies, CNR, Milano, Italy
}

Received November 11, 2005; Accepted December 29, 2005

\begin{abstract}
High consumption of phytoestrogen-rich food correlates with reduced incidence of breast cancer. However, the effect of phytoestrogens on growth of pre-existing breast tumors presents concerns when planning the use of phytoestrogens as chemoprevention strategy. Genistein, the active phytoestrogen in soy, displays weak estrogenic activity mediated by estrogen receptor (ER) with a preferential binding for the ER-B species. However, no information is at present available on the interaction between phytoestrogens and the various isoforms generated by alternative splicing. In two human breast cancer cell lines, T47D and BT20, which express variable levels of ER- $\beta$, the effect of genistein and quercetin was evaluated singly and in comparison with 17ß-estradiol, on mRNA expression of estrogen receptor- $\beta$ (ER- $\beta$ ) isoforms evaluated by a triple primer RT-PCR assay. In T47D cells estradiol caused a 6-fold up-regulation of total ER- $\beta$, and modified the relative expression pattern of the various isoforms, up-regulating the $\beta 2$ and down-regulating the $\beta 5$ isoform. Genistein up-regulated ER- 32 and ER- 31 in T47D cells, and after treatment the ER- 32 isoform became prevalent, while in BT20 cells it almost doubled the percent contribution of ER- $\beta 1$ and ER- $\$ 2$ to total ER- $\beta$. Quercetin did not alter the total levels nor the percent distribution of ER- $\beta$ isoforms in either cell line. Genistein, through the modulation of ER- $\beta$ isoform RNA expression inhibited estrogen-promoted cell growth, without interfering on estrogen-regulated transcription. ER- $\beta$ and its ER- $\beta$ mRNA isoforms may be involved in a selflimiting mechanism of estrogenic stimulation promoted either by the natural hormone or by weaker estrogen agonists like genistein.
\end{abstract}

Correspondence to: Dr Vera Cappelletti, Department of Experimental Oncology, Unit \#10, Istituto Nazionale Tumori, Via Venezian 1, I-20133 Milan, Italy

E-mail: vera.cappelletti@istitutotumori.mi.it

Key words: breast cancer, estrogen receptor- $\beta$ splicing variants, genistein, quercetin, cell growth

\section{Introduction}

Isoflavones, which are present in large amounts in soy beans, are able to protect against three major socially important diseases, i.e. cancer, coronary heart disease and menopausal symptoms (mainly osteoporosis) (1).

Some concern about the potential ability of isoflavones to stimulate breast cancer growth in women has been raised by the observation that two-week dietary supplementation with soy increased pS2 levels in normal breast of premenopausal women (2). However, this is a typical estrogenic effect not necessarily linked to proliferation (3).

Among the isoflavones, genistein is considered as a selective estrogen receptor modulator and has therefore recently been proposed as a safe alternative to conventional hormone replacement therapy (1). Quercetin is contained in many edible fruits and vegetables (4) and exerts growth inhibitory activity on human breast cancer $(5,6)$ as well as on other neoplasias.

While estrogens trigger the transcriptional activation and repression of both estrogen receptor isoforms, ER- $\alpha$ and ER- $\beta$, genistein is almost exclusively ER- $\beta$ selective inasmuch as the relative binding affinity of ER- $\beta$ for genistein is 30 -fold higher than that of ER- $\alpha$ (7); once bound, genistein selectively recruits co-regulators to ER- $\beta$. Furthermore, the ER- $\beta$-genistein complex induces a peculiar orientation in the AF-2 helix that is different from the 'agonist position' and very similar to the orientation induced by ER antagonists (8). Such conformation justifies the partial antagonist nature of genistein, explains its well-known protective effect (9), and indirectly sheds more light on the controversial biological role of ER- $\beta$ in the mammary gland, further supporting its function as a negative regulator of estrogenic action (10).

Although increasing evidence tends to link this receptor to the control of estrogenic over-stimulation, the function of ER- $\beta$ in normal and neoplastic breast tissue still remains obscure (11). Furthermore, various alternative splicing isoforms of ER- $\beta$ have been described in addition to the wild-type ER-ß (ER-ß1): ER-ß2, ER-ß4 and ER- 35 , all lacking exon 8 but sharing the 3 '-end sequence with ER-ß1 (12-14). ER-ß32 (also called ER-ßcx) appears to be particularly interesting because it shows significant dominant negative activity only against ER- $\alpha$ transactivation (13). The ER- 32 isoform differs from $\beta 1$ in the replacement of exon 8 by a distinct sequence encoding for 26 amino acid residues and for in expression at higher mRNA levels in breast cancer compared to $\beta 1(15,16)$. 
It does not bind estradiol $(13,17)$ and therefore does not directly activate ERE-controlled transcription; however, it interacts with ER- $\alpha$ in that it abolishes its transcriptional activity by impairing its DNA binding (13).

Alternative splicing is a major mechanism which generates diversity in the human transcriptome and its regulation is an important means of physiological control. Alternative splice data might have therefore the potential to substantially contribute to our understanding of biological processes involving ER-ß (18).

In the present study we investigated the effect of the phytoestrogens genistein and quercetin compared to $17 ß$-estradiol on ER- $\alpha$ and ER- $\beta$ mRNA expression in two breast cancer cell lines differing in hormone sensitivity and ER content. Our results showed the presence of a self-limiting mechanism of estrogenic stimulation sustained by ER- $\beta$ and particularly by its $\beta 2$ isoform.

\section{Materials and methods}

Chemicals. Cell culture reagents were from Sigma (St. Louis, $\mathrm{MO}$ ) and from BioWhittaker Europe (Vervier, BE); [ $\left.{ }^{32} \mathrm{P}\right]-\mathrm{dCTP}$ was from the Radiochemical Center Amersham (Amersham, UK). Kits for transcription and PCR were from Roche (Roche Diagnostics, Mannheim, Germany) and Applied Biosystems (Foster City, CA), respectively. Genistein was purchased from Invitrogen (Milan, Italy) and quercetin was obtained from Aldrich (Steinheim, Germany). All other chemicals were of analytical grade.

\section{Cell lines}

Cell growth experiments. For cell growth experiments, T47D cells maintained in DMEM/F12, were seeded in T25 flask, allowed to attach for $24 \mathrm{~h}$ and passed to medium supplemented with 5\% charcoal-stripped serum. Pre-treatment (hereafter referred as 'cell priming') with $5 \mu \mathrm{M}$ genistein, $0.1 \mu \mathrm{M}$ estradiol or vehicle alone, was carried at for 2 days in T25 flasks at a cell density of 38,000 cells $/ \mathrm{cm}^{2}$. Primed cells were collected by trypsin-EDTA treatment, counted and seeded in triplicate into 6-well culture plates at a density of 104,000 cells/ $\mathrm{cm}^{2}$. Cell growth was assessed in medium supplemented with $0.01 \mu \mathrm{M}$ estradiol after 6 days by cell counting.

Human breast cancer cell lines were kindly provided by Dr K. Horwitz, University of Colorado, Denver. Cells were maintained in DMEM/F12 (Sigma) without phenol red and supplemented with $5 \%$ heat-inactivated fetal bovine serum (FBS) and $4 \mathrm{~g} / 1$ glucose. Treatments, carried out in medium supplemented with charcoal-stripped serum, consisted of 12 , 24 and 48-h cultures with 17ß-estradiol $(0.01,0.1,1 \mu \mathrm{M})$ obtained from a stock solution in ethanol, genistein $(5,15$, $30 \mu \mathrm{M}$ ) obtained from a stock solution in DMSO and quercetin $(1,5,10 \mu \mathrm{M})$ obtained from a stock solution in ethanol. In control samples the vehicle substituted for the treatment substance.

$R T$-PCR. Total RNA was extracted directly from cell monolayers with the commercially available reagent TRIzol (Life Technology, Inc., Grand Island, NY). The integrity and purity of spectrophotometrically quantified extracted RNA were checked by electrophoresis.
Total RNA $(1 \mu \mathrm{g})$ was reverse-transcribed using the commercially available first-strand cDNA synthesis kit for RT-PCR (AMV) (Roche Diagnostics) after incubation at $65^{\circ} \mathrm{C}$ for 15 min to remove secondary RNA structures according to the manufacturer's instructions. The obtained cDNA was used for subsequent amplifications.

Determination of ER- $\alpha$ and $E R-\beta$ isoform and $p S 2 \mathrm{mRNA}$ expression. Amplification of ER- $\alpha$ cDNA was carried out in triplicate as previously described (19). The ubiquitously expressed $\beta$-actin gene was amplified in parallel. To exclude variations in $\beta$-actin expression induced by treatment (20), two additional housekeeping genes (S18 and GAPDH) were amplified in parallel showing patterns of expression superimposable to those of $\beta$-actin. The mean densitometric data adjusted for $\beta$-actin expression were recorded as percentages of the control.

Semiquantitative determination of ER- $\beta 1$ and its isoforms ER- $\beta 2$ and ER-B5 was performed in triplicate by a tripleprimer PCR using the following primers: ER- $31 \mathrm{U}, 5$ '-CGA TGC TTT GGT TTG GGT GAT-3' sense located in exon 7 (1400-1420), GeneBank accession no. AB006590; ER-ß1L, 5'-GCC CTC TTT GCT TTT ACT GTC-3' antisense located in exon 8 (1667-1648), GeneBank accession no. AB006590; ER-ß2L, 5'-CTT TAG GCC ACC GAG TTG ATT-3' antisense located in ER-B2 alternative sequences, positions 1933-1913, GeneBank accession no. AF051428.

The PCR reaction was the same as the one used for ER- $\alpha$ with $4 \mathrm{ng} / \mu 1$ each of the $1 \mathrm{U}, 1 \mathrm{~L}$ and $2 \mathrm{~L}$ primers and $0.25 \mathrm{ng} / \mu 1$ each of the sense and antisense $\beta$-actin primers. The following amplification conditions were used for co-amplification of $\beta$-actin and ER- $\beta$ isoforms: a single step of $10 \mathrm{~min}$ at $95^{\circ} \mathrm{C}$ to activate the enzyme, followed by 30 cycles of denaturation at $95^{\circ} \mathrm{C}$ for $30 \mathrm{sec}$, annealing at $60^{\circ} \mathrm{C}$ for $30 \mathrm{sec}$, elongation at $72^{\circ} \mathrm{C}$ for $1 \mathrm{~min}$ and a final single step at $72^{\circ} \mathrm{C}$ for $5 \mathrm{~min}$.

Besides a 600 -bp band corresponding to $\beta$-actin, the following products 295,268 and 214 bp were obtained respectively corresponding to ER-B5, ER-B1 and ER-B2 (21). The ER-ß34, was not expressed in breast cancer.

The conditions for co-amplification were accurately determined with respect to the primer concentration in order to guarantee comparable amplification efficiencies between the highly expressed standard and the target gene expressed at lower levels. The linearity of the amplification reaction with respect to cycle number and cDNA amount was verified to allow semiquantitative estimates of the level of messengers.

Radioactive PCR products were separated on a $6 \%$ polyacrylamide gel under non-denaturating conditions. Gels were dried and the intensity of the radioactive signal was detected using a phosphoroimager (Thypoon Scanner, Molecular Dynamics). The mean densitometric data for each single ER- $\beta$ isoform were adjusted for $\beta$-actin expression and were recorded as percentages of the control. The relative percent-age of each isoform with respect to the sum of the signals $(\beta 1+\beta 2+\beta 5)$ was also calculated and used for correlative studies.

pS2 amplification was carried on with a non-radioactive protocol using the same master mix as described for ER- $\alpha$ and ER- $\beta$ isoforms with a $1-\mu \mathrm{M}$ concentration of following primers: pS2 sense, 5'-TTT GGA GCA AGG AGG CAA 
a.

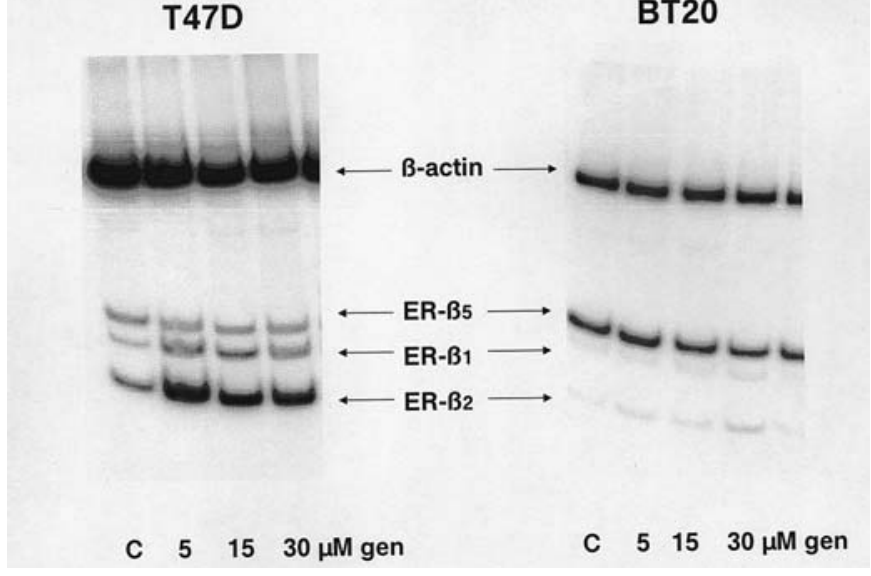

Figure 1. Results from the evaluation of ER- $\beta$ isoforms by RT-PCR triple primer assay. T47D and BT20 cells treated for $12 \mathrm{~h}$ with vehicle only (lane 1), $5 \mu \mathrm{M}$ (lane 2), $15 \mu \mathrm{M}$ (lane 3) and $30 \mu \mathrm{M}$ (lane 4) genistein. Amplification products for ER- 35 (295 bp), ER-ß1 (268 bp), ER-B2 (214 bp) and the housekeeping gene $\beta$-actin $(600 \mathrm{bp})$ were separated in a $6 \%$ polyacrylamide gel under non-denaturating conditions.

TGG-3'; pS2 antisense, 5'-TGG TAT TAG GAT AGA AGC ACC AGG G-3'.

The following amplification conditions were used: a single 10 min step at $95^{\circ} \mathrm{C}$ to activate the enzyme, followed by 31 cycles of denaturation at $94^{\circ} \mathrm{C}$ for $45 \mathrm{sec}$, annealing at $64^{\circ} \mathrm{C}$ for $45 \mathrm{sec}$, elongation at $72^{\circ} \mathrm{C}$ for $55 \mathrm{sec}$ and a final single step at $72^{\circ} \mathrm{C}$ for $5 \mathrm{~min}$. The amplification product was run on a $1 \%$ agarose gel in TAE buffer.

Data analysis. Data are presented as means $\pm \mathrm{SE}$ of three independent experiments. Differences between ER expression in control and treated cells were tested by two-tailed Student's $\mathrm{t}$-test. Results were considered significant at $\mathrm{p}<0.05$ (22).

\section{Results}

T47D and BT20 cells represent hormone-sensitive and hormone-insensitive cell lines, respectively. As expected, this biological difference was reflected by a different ER- $\alpha$ profile (19), but also the ER- $\beta$ expression was different. T47D cells expressed about 2.5-fold higher levels of total ER- $\beta$ with respect to BT20 cells (data not shown). They also differed in terms of relative percentages of the $B 1, \beta 2$ and $B 5$ isoforms (Fig. 1). The prevalent isoform was $B 2$ in T47D cells (accounting for up to 50\% of the total ER-B) and B5 (accounting for up to $84 \%$ of the total ER-ß signal) in BT20 cells.

Effects on ER- $\beta$ and its isoforms. Treatment with estradiol, genistein and quercetin triggered modifications in the total ER- $\beta$ levels as well as in the relative percentages of the isoforms. As no time dependency was observed overall, only results for the 48-h treatment are reported. A representative gel, reporting the effects of genistein treatment on ER- $\beta$ isoforms in both cell lines is shown in Fig. 1.

Effects of 17ß-estradiol. Cells were treated with estradiol at concentrations ranging from 0.01 to $1 \mu \mathrm{M}$ in medium supplemented with charcoal-stripped serum.
A.

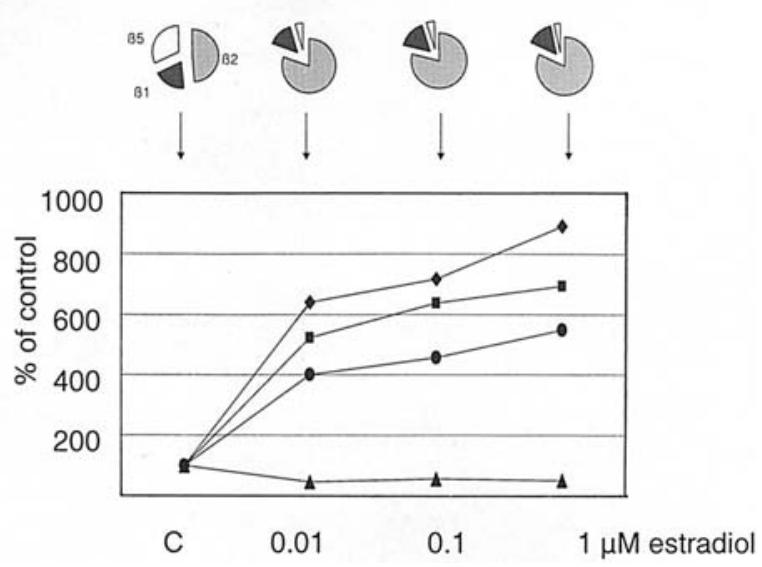

B.

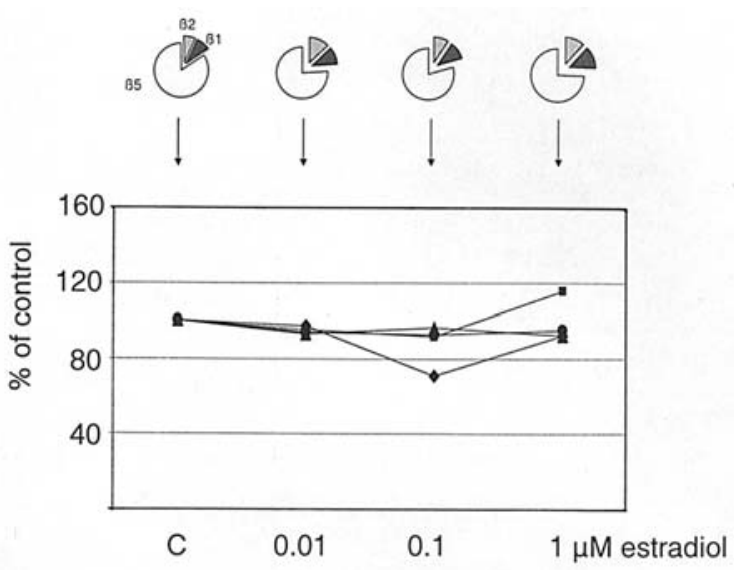

Figure 2. ER- $B$ isoform mRNA expression after treatment with estradiol in T47D (A) and BT20 cells (B). The upper panel reports the relative percent distribution of ER-B1, ER-B2 and ER- 35 . The lower panel reports modulations

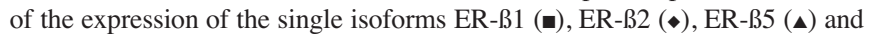
of their sum $(\bullet)$ upon treatment as a function of treatment dose. Data are the means of triplicate determinations, adjusted for $\beta$-actin expression and recorded as percentages of the control. For T47D cells, statistically significant differences with respect to the control, were observed for ER-\$1, ER-\$2 and total ER- $\beta$ at the two highest concentrations and for ER- $B 5$ after treatment with $0.01 \mu \mathrm{M}$ estradiol. For BT20 cells no statistically significant differences were observed.

At the highest tested concentration, estradiol caused a more than 5 -fold $(\mathrm{p}<0.01)$ up-regulation of total ER- $\beta$ in T47D cells, mainly due to the ER- $\beta 2$ and ER- $\beta 1$ isoforms, which increased 8- and 6-fold, respectively, compared to the control $(p<0.05)$. By contrast, the ER-B5 isoform was down-regulated by the treatment to about $50 \%$ of the control values $(p<0.02)$. Consequently, the relative composition of the total ER- $\beta$ signal also underwent treatment-induced variations. ER-B2, which was the main form in the untreated control cells, increased from $50 \%$ to about $80 \%$ after treatment with estradiol. Such effect did not appear to be dose-dependent (Fig. 2A). The percent increase of the $\beta 2$ form was compensated by a decrease in the relative ER- 35 percentage from $32 \%$ to about $5 \%$. The relative contribution of the wild-type $\beta 1$ to the total signal remained mostly unchanged upon estradiol treatment.

Estradiol treatment of the hormone-insensitive BT20 cells did not induce any significant variation in the total ER- $\beta$ mRNA levels (Fig. 2). None of the ER-B isoforms underwent any significant change in expression levels and their relative contribution was not altered by the treatment. 
A.

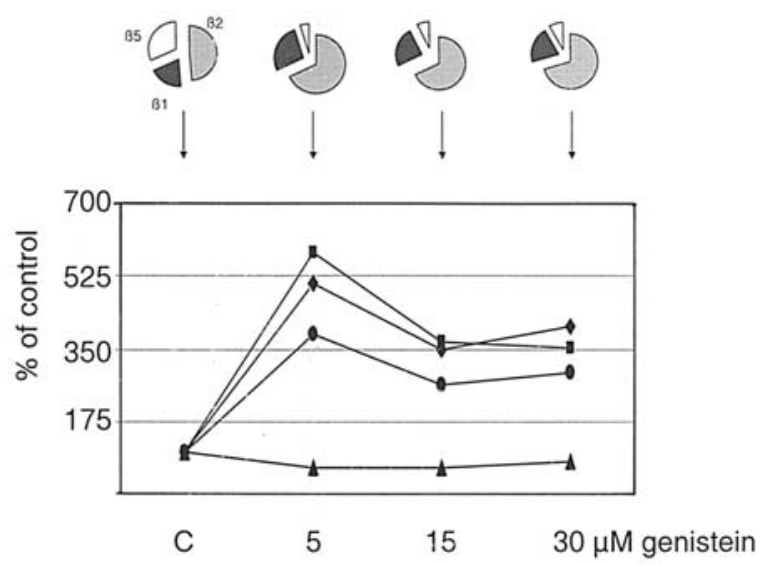

B.

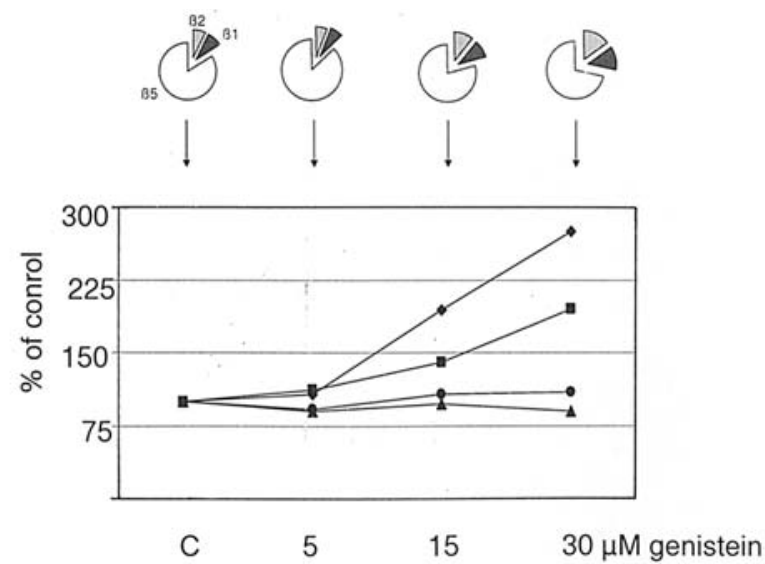

Figure 3. ER-B isoform mRNA expression after treatment with genistein in T47D (A) and BT20 cells (B). The upper panel reports the percent distribution of ER-B1, ER-B2 and ER-B5. The lower panel reports modulations of the

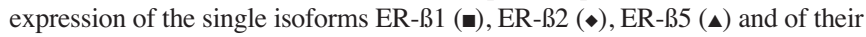
sum $(\bullet)$ upon treatment as a function of treatment dose. Data are the means of triplicate determinations, adjusted for $\beta$-actin expression and recorded as percentages of the control. For T47D cells, statistically significant differences with respect to the control, were observed for ER- $\beta 1$, ER-B2 and total ER- $\beta$ at all concentrations. ER-B5 levels were non-significantly different from control at all tested concentrations. For BT20 cells, statistically significant differences with respect to the control were observed for ER-B2 at the 15 and $30 \mu \mathrm{M}$ doses, and for ER- $\beta 1$ at the $30 \mu \mathrm{M}$ dose.

Effects of genistein. T47D cells were treated with genistein at concentrations ranging from 5 to $30 \mu \mathrm{M}$ (Fig. 3A). Treatment induced up-regulation of the total ER- $\beta$ levels which was more marked at the lowest concentration tested $(385 \%$ of control, $\mathrm{p}<0.025)$ compared to the two highest concentrations (264\% and $293 \%$ of control, respectively, $\mathrm{p}<0.02$ ). A similar modulation pattern was observed for ER- 32 and wild-type $\beta 1$, with approximately 4 - and 5-fold up-regulation with respect to the control ( $\mathrm{p}<0.025$ and $<0.05$, respectively) at the $5 \mu \mathrm{M}$ concentration. Conversely, the $\beta 5$ isoform was slightly but not significantly down-regulated $(\mathrm{p}<0.10)$ to about $60 \%$ and $77 \%$ of the control, respectively, in the presence of 5 or $15 \mu \mathrm{M}$ and of $30 \mu \mathrm{M}$ genistein.

The treatment also caused a change in the relative percent composition of the various isoforms. The ER-B2 isoform, which represented $50 \%$ of the total ER- $\beta$ isoforms in the controls, accounted for $70 \%$ of the total after genistein treatment. The ER- $B 5$ isoform dropped from as much as $32 \%$ of the total $\beta$ signal to $5 \%-8 \%$, regardless of the genistein
A.

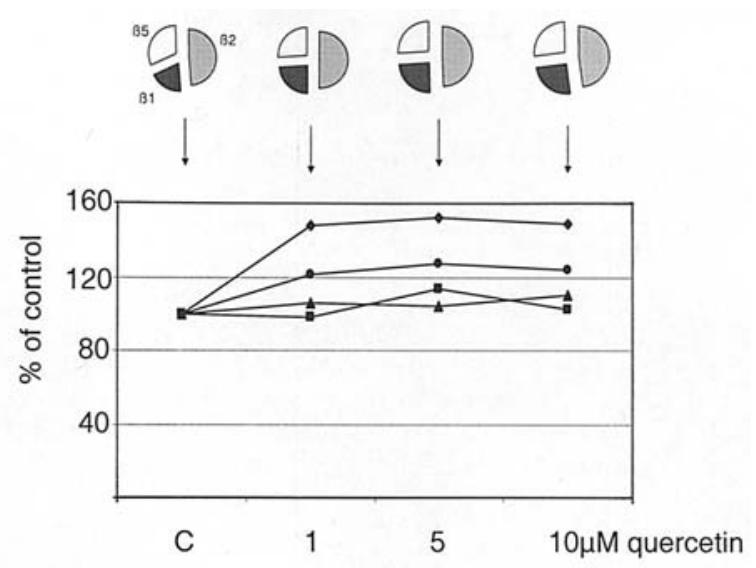

B.

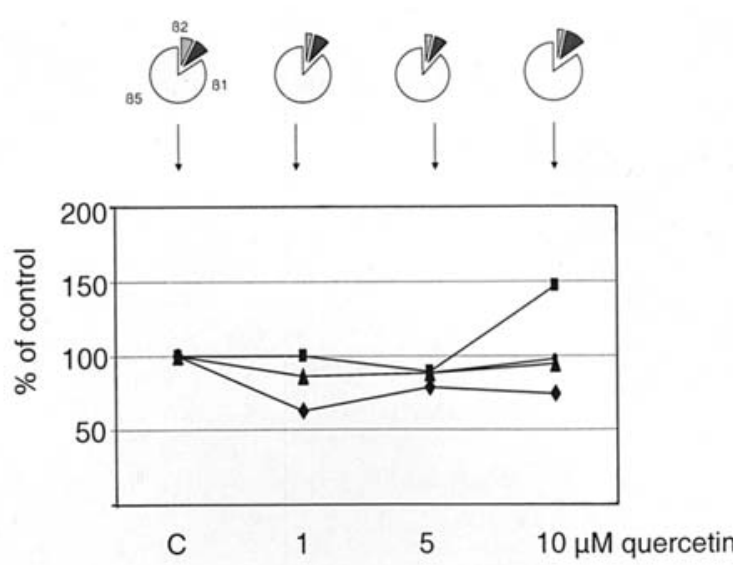

Figure 4. ER- $B$ isoform mRNA expression after treatment with quercetin in T47D (A) and BT20 cells (B). The upper panel reports the percent distribution of ER-B1, ER-B2 and ER-B5. The lower panel reports modulations of the

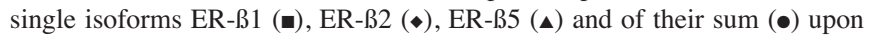
treatment as a function of treatment dose. Data are the means of triplicate determinations, adjusted for $B$-actin expression and recorded as percentages of the control. For T47D cells, statistically significant differences with respect to the control were observed for ER- 32 at all tested doses. For BT20 cells no statistically significant differences were observed.

concentration. The wild-type ER- $\beta 1$ isoform, which represented $19 \%$ of the total species, accounted for $27 \%$ after treatment with $5 \mu \mathrm{M}$ genistein and $22 \%$ after treatment with $30 \mu \mathrm{M}$ genistein.

In the BT20 cell line genistein did not significantly affect the total ER- $\beta$ expression profile, which was similar to the control at all tested concentrations (Fig. 3B). Similarly, the B5 isoform was not modulated, while $\beta 2$, and to a lesser extent $\beta 1$, were up-regulated to $274 \%$ and $194 \%$ with respect to the control ( $p<0.005$ and $<0.02$, respectively) in a dosedependent fashion after treatment with 15 and $30 \mu \mathrm{M}$ genistein. The relative percent contribution of the tested isoforms to the total ER- $\beta$ species was also affected by treatment. In the presence of $30 \mu \mathrm{M}$ genistein the expression of ER- $\beta 1$ and ER-B2 increased about 2-fold compared to untreated controls.

Effects of quercetin. T47D cells were treated with 1, 5, and $10 \mu \mathrm{M}$ quercetin. There was a slight but not statistically significant increase in the total ER-ß levels (Fig. 4A), mainly due to the ER-B2 isoform which was up-regulated to $152 \%$ $(\mathrm{p}<0.05)$ of the control, regardless of the dose. Absolute and 
Table I. Modulation of ER- $\alpha$ mRNA expression ${ }^{\mathrm{a}}$ in T47D and BT20 cells.

\begin{tabular}{ccc}
\hline & T47D & BT20 \\
\hline $\begin{array}{cc}\text { 17ß-estradiol }(\mu \mathrm{M}) \\
\text { Vehicle }\end{array}$ & $100 \pm 7.9^{\mathrm{b}}$ & $100 \pm 4.3$ \\
0.01 & $92.8 \pm 4.5$ & $87.5 \pm 2.2$ \\
0.1 & $146.4 \pm 6.7^{\mathrm{c}}$ & $143.7 \pm 24.9^{\mathrm{c}}$ \\
1 & $159.3 \pm 2.2^{\mathrm{c}}$ & $131.9 \pm 3.1^{\mathrm{c}}$ \\
Genistein $(\mu \mathrm{M})$ & & \\
Vehicle & $100 \pm 3.4$ & $100 \pm 2.5$ \\
5 & $98.5 \pm 4.2$ & $138.9 \pm 7.1^{\mathrm{c}}$ \\
10 & $62.5 \pm 2.5^{\mathrm{c}}$ & $205.5 \pm 50.7^{\mathrm{c}}$ \\
30 & $87.1 \pm 6.2$ & $107.4 \pm 9.2$ \\
Quercetin $(\mu \mathrm{M})$ & & \\
Vehicle & $100 \pm 4.9$ & $100 \pm 1.6$ \\
1 & $102.1 \pm 3.9$ & $99.3 \pm 14.4$ \\
5 & $72.8 \pm 0.9^{\mathrm{c}}$ & $88.8 \pm 4.5$ \\
10 & $78.5 \pm 4.6^{\mathrm{c}}$ & $107.7 \pm 0.2$ \\
\hline
\end{tabular}

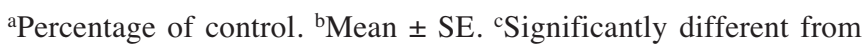
control, $\mathrm{p}<0.05$ two-tailed t-test.

relative ER-B1 and ER- 35 did not change after treatment with quercetin. In the BT20 cells line neither total ER- $\beta$ nor single isoform mRNA was significantly modified by the treatment (Fig. 4B).

Effects on ER- $\alpha$. The effects on the mRNA expression of ER- $\alpha$ were not as dramatic as those on ER-B. In Table I data are reported for 48-h treatments. It can be observed that, except for the lowest concentration tested, i.e. $0.01 \mu \mathrm{M}$, estradiol causes about $50 \%$ up-regulation with respect to control both in T47D and BT20 cells. Up-regulation of ER- $\alpha$ mRNA was observed with the two lower concentrations of genistein, but only in BT20 cells. Quercetin did not exert any effect in BT20 cells, while at the highest concentrations it slightly lowered ER- $\alpha$ in T47D cells.

Effects on cell growth. In order to evaluate the effect of ER- $\beta$ isoform modulation on subsequent estrogenic growth stimulation, T47D cells were pre-treated for $48 \mathrm{~h}$ respectively with $10^{-7} \mathrm{M} 173$-estradiol, $5 \mu \mathrm{M}$ genistein or vehicle. Primed cells were collected, re-seeded in medium containing $10^{-8} \mathrm{M}$ estradiol and grown for 6 days. Cells, derived from triplicates were collected and counted. Data are shown in Fig. 5 as percentages of unprimed control. It clearly appears that priming

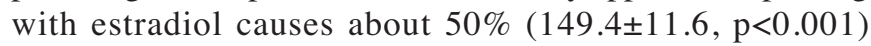
potentiation of estrogenic stimulation, while priming with genistein potentiates the estrogenic stimulatory effect only by about $20 \%(120.3 \pm 9.1)$.

Effects on $p S 2$. The pattern of induction of $\mathrm{pS} 2$ by estrogen was also evaluated in untreated cells and in cells primed

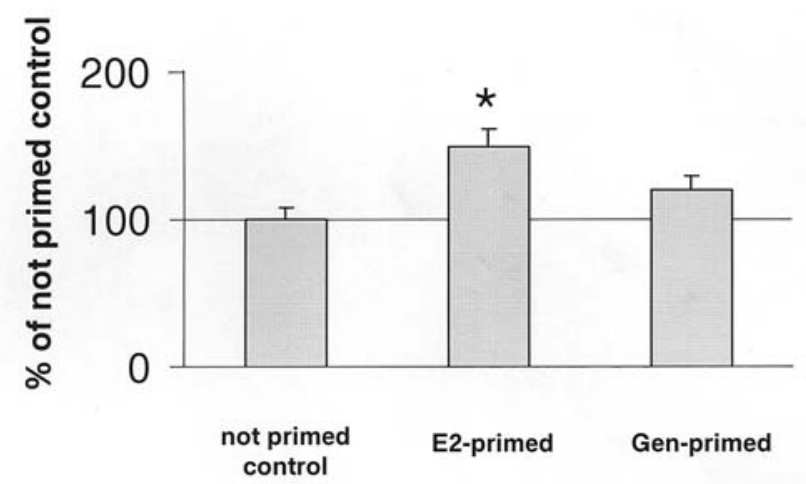

Figure 5. Cell growth variations in T47D cells upon treatment with $0.01 \mu \mathrm{M}$ estradiol for 6 days. Cells were grown in 6-well culture plates in DMEM/ F12 supplemented with charcoal-treated 5\% FBS. Experimental medium was changed every three days, cells were collected by trypsin-EDTA treatment after 6 days when they were still in the exponential phase of their growth and counted. Results are the mean of triplicates and are reported as percentages of cell number of the not-primed control. The asterisk indicates values statistically different from the not primed control.

Table II. Effect of pre-treatment with phytoestrogens on estradiol-induced pS2 transcription in T47D cells.

\begin{tabular}{lccccc}
\hline & \multicolumn{2}{c}{ Estradiol for 4 days } & & \multicolumn{2}{c}{ Estradiol for 7 days } \\
\cline { 2 - 3 } \cline { 6 - 7 } Pre-treatment & $10^{-11} \mathrm{M}$ & $10^{-8} \mathrm{M}$ & & $10^{-11} \mathrm{M}$ & $10^{-8} \mathrm{M}$ \\
\hline Vehicle & $465 \pm 97.6^{\mathrm{a}}$ & $307 \pm 26$ & & $270 \pm 76.7$ & $366 \pm 15.1$ \\
$5 \mu \mathrm{M}$ gen & $412 \pm 145$ & $239 \pm 3.2$ & & $243.2 \pm 77.8$ & $382 \pm 66.4$ \\
$5 \mu \mathrm{M}$ quer & $432.7 \pm 139.9$ & $209 \pm 36$ & & $200 \pm 36$ & $349 \pm 73.3$ \\
\hline
\end{tabular}

apercentage of untreated control $\pm \mathrm{SE}$.

respectively with vehicle, genistein and quercetin. Cells were primed for $48 \mathrm{~h}$ and thereafter treated with estradiol $10^{-8}$ and $10^{-11} \mathrm{M}$ for 4 and 7 days.

Results are reported in Table II. It clearly appears that after 4 days of stimulation with $10^{-11}$ and $10^{-8} \mathrm{M}$ estradiol, pS2 mRNA levels were significantly up-regulated, independently of the adopted pre-treatment scheme. The strongest upregulation was observed following treatment with $10^{-11} \mathrm{M}$ estradiol for 4 days, while with the same dose, a prolonged treatment time led to a weaker stimulation of $\mathrm{pS} 2$ mRNA levels.

\section{Discussion}

Estrogens, which are administered to many women to control adverse menopausal effects, increase the risk of breast cancer. Interestingly, the intake of plant-derived estrogens (phytoestrogens) has been found to be associated with a lower breast cancer incidence. Such paradoxical effects are not yet well understood at the molecular level and still many concerns exist about the use of phytoestrogens as safe hormone replacement therapy (23).

In a previous study in which we compared various effects of genistein and quercetin on estrogen receptor functions 
(growth stimulation/inhibition, nuclear translocation, expression of estrogen-regulated genes such as progesterone receptor, pS2 and cathepsin D), we observed that quercetin acts as a pure antiestrogen that does not bind the ER- $\alpha$ but prevents its interaction with the ERE, whereas genistein acts as a mixed estrogen-agonist/antagonist (3).

The partial estrogen antagonist nature of genistein could depend on its preferential binding to ER- $\beta$ (7), which has been described as a negative regulator of estrogen-regulated transcription (10). In the present study we investigated further the paradoxical effects of genistein, which is protective against breast cancer risk, but still is a positive modulator of estrogenregulated proteins like pS2 and cathepsin D (24) and compared it to qurcetin. Our hypothesis was that genistein could act by selectively regulating ER- $\beta$ and that up-regulation of ER- $\beta$ could modify estrogen effects on hormone-sensitive cells. We therefore tried to link the data on ER- $\beta$ isoform modulation to effects of estrogen on both growth and estrogen-regulated protein, i.e. pS2.

Various ER- $\beta$ isoforms generated by alternative splicing have been reported in addition to the wild-type ER- $\beta$ known as ER- 31 . Among them ER- 32 (also called ER-ßcx) was described as a potential inhibitor of estrogenic action (13). The 32 isoform neither binds estradiol nor forms complexes with the ERE. Microarray gene expression analysis has demonstrated that MCF-7 cells transfected with the $\beta 2$ isoform display a different gene expression profile from the parental cell line and the one transfected with the $\beta 1$ isoform (25). This would suggest a specific role for ER- $\beta 2$, and ER- $\beta$ isoforms in general, in addition to prompting further investigation into different models. We therefore set out to investigate whether genistein, quercetin and estradiol selectively regulate the expression of ER- $\beta$ and its isoforms with respect to ER- $\alpha$. Our aim was to gain insight into the mechanism of action of phytoestrogens and to better understand the role of the ER- $\beta$ isoforms.

The modulation of ER mRNA levels was compared in typically hormone-sensitive (T47D) and hormone-independent cell lines (BT20) characterized by detectable or undetectable ER- $\alpha$ protein levels. ER messengers were, however, detectable, although at different levels in both cell lines.

Generally, the reported effects were much more striking in the case of ER- $\beta$ and its isoforms compared to modulation of ER- $\alpha$, independently of the ER expression pattern of the considered cell line.

Treatment with estradiol strongly increased total ER- $\beta$ expression in hormone-sensitive T47D cells. The ER- $B$ upregulation was mainly due to an increase in the ER- 32 and wild-type ER- $B 1$ isoforms and was not observed in the hormone-insensitive BT20 cell line. The enhanced expression of ER-ß2, an ER- $\beta$ isoform that does not bind estradiol and does not interact with DNA-responsive elements, is rather peculiar, especially if we consider its reported role as a regulator of ER- $\alpha$ activity. In fact, after treatment with the hormone, mRNA of the 32 isoform, which accounted for $50 \%$ of the total ER- $\beta$ species mRNA, increased to about $80 \%$ of total ER- $\beta$. This result could be considered as an adaptation mechanism of the cell to continuous estrogenic stimulation. In keeping with this interpretation is the observation that ER-B2 mRNA was not modulated in the BT20 cell line.
This cell line is hormone-insensitive and displays almost undetectable ER- $\alpha$ protein levels. Genistein, which in hormonesensitive cell lines is estrogenic at low concentrations and antiestrogenic at higher concentrations, induced about 4-fold increase in total ER- $\beta$ mRNA levels (5- and almost 6-fold in ER- 32 and ER- $\beta 1$ levels, respectively) and a lesser increase (ranging between 2.6- and 4-fold) at higher concentrations. Also following treatment with genistein the relative percent distribution of the ER- $\beta$ mRNA isoforms was modified, with an increase in the $B 2$ and a decrease in the $B 5$ isoform. However, in the case of genistein the modulations and the treatment-induced modifications were also seen in the hormone-insensitive BT20 cell line. This finding is not surprising inasmuch as the relative binding affinity of genistein for ER- $\beta$ is about 30 -fold higher than for ER- $\alpha$. In BT20 cells, however, the modulation was different, since total ER- $B$ mRNA levels were unaffected by genistein, while the $\beta 2$ and to a lesser extent the $B 1$ isoforms were up-regulated. In both cases the relative percent contribution to the total ER- $\beta$ signal almost doubled.

Further support to these findings is also given by cell growth experiments carried out with estradiol in T47D cells. In this cell line pre-treatment with genistein inhibited cell growth following estradiol compared to pre-treatment with estradiol itself. It should however be noted that in both cases estradiol induced stimulation was stronger in estradiol and genistein pre-treated cells compared to vehicle pre-treated cells. This effect is probably due to the ER- $\alpha$ induction triggered by estradiol and genistein. While induction of ER- $\beta$ affected estrogen-regulated cell growth, no effects were exerted on typically estrogen-induced transcripts like $\mathrm{pS} 2$. In fact $\mathrm{pS} 2$ was induced by estradiol with a similar pattern regardless of pre-treatment with either genistein or quercetin to differentially modulate ER-B.

On the contrary, quercetin, which has been demonstrated to exert an antiestrogenic effect, did not significantly modify ER levels, although in T47D cells a trend towards a slight (1.5-fold) increase in ER-ß2 levels was observed.

It therefore appears that up-regulation of ER- $\beta$ mRNA isoforms is a typical response to estrogenic stimulation and is consequently more marked in estrogen-responsive cells. The phytoestrogen genistein, which has a binding preference for the ER- $\beta$ isoform, triggers up-regulation of ER- $\beta$ both in T47D and BT20 cells, although to a lesser extent in the latter, and leads to an increase in the relative proportion of the negative regulator ER- 32 .

We have already reported that up-regulation of ER- $\beta$ levels may represent a kind of self-limiting effect of prolonged estrogenic stimulation, which is, however, observed not only with canonical estrogens but also with less active and weaker xenoestrogens (19). This study reinforces such hypothesis and adds a further layer of complexity as it appears that wild-type ER- $\beta$ and its splicing isoforms are not regulated in the same way. This is in keeping with the emerging view that considers alternative splicing a major mechanism for expanding and regulating the repertoire of gene function (18).

Our results suggest that genistein through the modulation of ER- $\beta$ isoforms, inhibits estrogen-promoted cell growth, but does not interfere with estrogen-regulated transcription. 
This observation should help to clarify the present ambiguity about safety of phytoestrogens as chemoprevention or replacement therapy supporting their potential benefits.

Furthermore, our study confirms the observation that the wild-type ER- $\beta$ isoform is not the prevailing isoform in human breast tumors. In hormone-sensitive cells the prevailing ER- $\beta$ is the negative regulator ER- $\beta 2$, while in the hormoneinsensitive cell line BT20 the prevailing isoform is the ER3 , whose role is not yet understood.

\section{Acknowledgments}

The present research was financially supported by grants from the Italian Association for Cancer Research (AIRC) and from the Italian Health Ministry.

\section{References}

1. Upmalis DH, Lobo R, Bradley L, Warren M, Cone F and Lamia CA: Vasomotor symptom relief by soy isoflavone extract tablets in postmenopausal women: a multicenter, double-blind, randomized, placebo controlled study. Menopause 7: 236-242, 2000.

2. Hargreaves DF, Potten CS, Harding C, Shaw LE, Morton MS, Roberts SA, Howell A and Bundred NJ: Two-week dietary soy supplementation has an estrogenic effect on normal premenopausal breast. J Endocrinol Metab 84: 4017-4024, 1999.

3. Miodini P, Fioravanti L, Di Fronzo G and Cappelletti V: The two phyto-oestrogens genistein and quercetin exert different effects on oestrogen receptor function. Br J Cancer 80: 1150-1155, 1999.

4. Kuehnau J: The flavonoids, a class of semi-essential food components: their role in human nutrition. World Rev Nutr Diet 24: 117-191, 1976

5. Scambia G, Ranelletti FO, Benedetti-Panici P, Piantelli M, De Vincenzo R, Ferrandina G, Bonanno G, Capelli A and Mancuso S: Quercetin induces type-II estrogen binding sites in estrogen receptor negative (MDAMB-231) and estrogen receptor positive (MCF-7) breast cancer cell lines. Int J Cancer 54: 462-466, 1993

6. Singhal RL, Yeah YA, Prajda N, Olah E, Sledge GS and Weber G: Quercetin down-regulates signal transduction in human breast carcinoma cells. Biochem Biophys Res Commun 208: 425-431, 1995.

7. Kuiper GG, Carlsson B, Grandien K, Enmark E, Haggblad J, Nilsson S and Gustafsson JA: Comparison of the ligand binding specificity and transcript tissue distribution of estrogen receptors alpha and beta. Endocrinology 138: 863-870, 1997.

8. Pike AC, Brzozowski AM, Hubbard RE, Bonn T, Thorsell AG, Engstrom O, Ljungren J, Gustafsson JA and Carlquist M: Structure of the ligand-binding domain of oestrogen receptor beta in the presence of a partial agonist and a full antagonist. EMBO J 18: 4608-4618, 1999.
9. Adlercreutz H and Mazur W: Phyto-oestrogens and Western diseases. Ann Med 29: 95-120, 1997.

10. Pettersson K, Delaunay F and Gustafsson JA: Estrogen receptor beta acts as a dominant regulator of estrogen signaling. Oncogene 19: 4970-4978, 2000.

11. Speirs V, Carder PJ, Lane S, Dodwell D, Lansdown MRJ and Hanby AM: Oestrogen receptor $B$ : what it means for patients with breast cancer (Review). Lancet Oncol 5: 174-181, 2004.

12. Moore JT, McKee DD, Slentz-Kesler K, Moore LB, Jones SA, Horne EL, Su JL, Kliewer SA, Lehmann JM and Willson TM: Cloning and characterization of human estrogen receptor beta isoforms. Biochem Biophys Res Commun 247: 75-78, 1998.

13. Ogawa S, Inoue S, Watanabe T, Orimo A, Hosoi T, Ouchi Y and Muramatsu M: Molecular cloning and characterization of human estrogen receptor betacx: a potential inhibitor of estrogen action in human. Nucleic Acids Res 26: 3505-3512, 1998.

14. Vladusic EA, Hornby AE, Guerra-Vladusic FK and Lupu R: Expression of estrogen receptor beta messenger RNA variant in breast cancer. Cancer Res 58: 210-214, 1998.

15. Iwao K, Miyoshi Y, Egawa C, Ikeda N and Noguchi S: Quantitative analysis of estrogen receptor-beta mRNA and its variants in human breast cancer. Int J Cancer 88: 733-736, 2000.

16. Tong D, Schuster E, Seifert M, Czerwenka K, Leodolte S and Zeillinger R: Expression of estrogen receptor beta isoforms in breast cancer tissues and cell lines. Breast Cancer Res Treat 71: 249-255, 2002.

17. Peng B, Lu B, Leygue E and Murphy LC: Putative functional characteristics of human estrogen receptor-beta isoforms. J Mol Endocrinol 30: 13-29, 2003.

18. Resch A, Xing Y, Modrek B, Gorlick M, Riley R and Lee C: Assessing the impact of alternative splicing on domain interactions in the human proteome. J Proteome Res 3: 76-83, 2004.

19. Cappelletti V, Saturno G, Miodini P, Körner W and Daidone MG: Selective modulation of ER- $\beta$ by estradiol and xenoestrogens in human breast cancer cell lines. Cell Mol Life Sci 60: 567-576, 2003.

20. Cicatiello L, Ambrosino C, Coletta B, Scalona M, Sica V, Bresciani F and Weisz A: Transcriptional activation of jun and actin genes by estrogen during mitogenic stimulation of rat uterine cells. J Steroid Biochem Mol Biol 41: 523-528, 1992.

21. Leygue E, Dotzlaw H, Watson PH and Murphy LC: Expression of estrogen receptor beta1, beta2, and beta 5 messenger RNAs in human breast tissue. Cancer Res 59: 1175-1179, 1999

22. Cappelletti V, Fioravanti L, Miodini P and DiFronzo G: Genistein blocks breast cancer cells in the $\mathrm{G}_{2} \mathrm{M}$ phase of the cell cycle. $\mathrm{J}$ Cell Biochem 79: 594-600, 2000.

23. Limer JL and Speirs V: Phyto-oestrogens and breast cancer chemoprevention. Breast Cancer Res 6: 119-127, 2004.

24. Fioravanti L, Cappelletti V, Miodini P, Ronchi E, Brivio M and Di Fronzo G: Genistein in the control of breast cancer cell growth: insights into the mechanism of action in vitro. Cancer Lett 130: 143-152, 1998.

25. Omoto Y, Eguchi H, Yamamoto-Yamaguchi Y and Hayashi S: Estrogen receptor (ER) beta1 and betacx/beta2 inhibit ERalpha function differently in breast cancer cell line MCF7. Oncogene 22: 5011-5020, 2003 . 